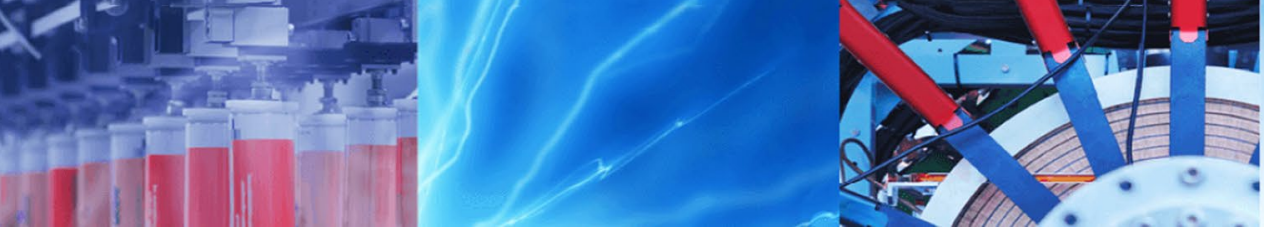

Short Communication

\title{
Stability appraisal of road cut slopes along a strategic transportation route in the Himalayas, Uttarakhand, India
}

\author{
Tariq Siddique $^{1}$ (D) Ejaj Ahmad Khan ${ }^{1}$
}

(c) Springer Nature Switzerland AG 2019

\begin{abstract}
In precarious mountain terrains like the Himalayas, road cut slopes are highly vulnerable to slope failures. Slope failures in the region are often triggered by natural factors such as neotectonism, rainfall, seismicity, weathering, erosion, etc. However, rapid human intervention is an additional factor causing large-scale slope instability in the region. Unplanned excavations of slopes for construction and/or widening of roads decrease slope stability. The inevitable slope failures cause major inconvenience to tourists and residents and are also responsible for severe injuries and loss of lives and property. The present study incorporates a stability analysis of road cut slopes along National Highway 58 (NH-58) from Kaliyasaur to Rudraprayag, Uttarakhand. Vulnerable slopes were identified during the field survey. To evaluate stability conditions of rock mass, rock mass classification systems including rock mass rating (RMR), continuous slope mass rating and the Geological Strength Index (GSI) were employed to identify different stability grades. Furthermore, quantified GSI was correlated with basic RMR in a bivariate plot, which showed a linear relationship. Kinematic analysis was also carried out to identify the probability of structurally controlled failures due to adversely oriented discontinuities. Outcomes from different methods corroborated each other and matched the existing site conditions.
\end{abstract}

Keywords Slope stability $\cdot$ Rock mass classification $\cdot$ RMR $\cdot$ CSMR $\cdot$ GSI $\cdot$ Kinematic analysis

$\begin{array}{ll}\text { List of abbreviations } \\ \text { RMR } & \text { Rock mass rating } \\ \text { CSMR } & \text { Continuous slope mass rating } \\ \text { GSI } & \text { Geological strength index } \\ \text { NDMA } & \text { National disaster management authority } \\ \text { NIDM } & \text { National Institute of Disaster Management } \\ \text { NH-58 } & \text { National Highway } 58 \\ \text { UCS } & \text { Uniaxial compressive strength } \\ \text { RQD } & \text { Rock quality designation } \\ \text { SMR } & \text { Slope mass rating } \\ \text { SCR } & \text { Surface condition rating } \\ \text { SR } & \text { Structure rating } \\ \text { ISRM } & \text { International Society of Rock Mechanics }\end{array}$

\section{Introduction}

Landslides are significant hazards that can be disastrous to property and often claim a death toll. As per the National Disaster Management Authority [29], 15\% (approximately 0.49 million $\mathrm{km}^{2}$ ) of the area including the Himalayas, the Arakan-Yoma belt in the northeastern region, the western Ghats and Nilgiri Hills is marked as a critical region for landslides in India. In the Uttarakhand Himalayas, road and highway networks act as arteries and a lifeline for various socio-economic developmental activities. Lacking a railway network and airfields, the region depends exclusively on roads for communication and transportation. In these precarious terrains, roads are constructed along the hills by excavating slopes. Often excavation for road construction and widening projects is done using faulty geoengineering techniques because of insufficient

Tariq Siddique, tariqsiddiqueiitr@gmail.com; Ejaj Ahmad Khan, ejajgh1868@gmail.com | 'Department of Geology, Aligarh Muslim University, Aligarh 202002, India.

SN Applied Sciences (2019) 1:409 | https://doi.org/10.1007/s42452-019-0433-4

Received: 7 February 2019 / Accepted: 29 March 2019 / Published online: 5 April 2019 
consideration of certain geological and geotechnical factors that cause slope instability [53]. To address the persistent threat of landslides, Mondal et al. [26] recommended performing fractional and controlled blasting during excavation. The stability of natural or engineered slopes is governed by many factors including the lithology, structural discontinuities, degree of weathering, relief, rainfall, seismicity, anthropogenic activities, etc. [21, 24, $32,37,47,48,56,59]$. The interplay of discontinuities in rocks and other geological and geotechnical parameters is a primary causes of slope failures $[15,18,20,27,34,49$, $57,58]$. The prevailing structural conditions and the nature of the slope-forming material also play significant roles in slope failure [35]. Roads in the Himalayan terrain often experience large-scale devastation due to landslides. Many sections, particularly those manifesting major discontinuities, are threatened by landslides. Slope stability analysis along roadways constitutes an important aspect of studies assessing landslide vulnerability. Vulnerability analysis of engineered slopes is of paramount importance for landslide hazard assessment [25]. Despite major improvements and breakthroughs in the recognition, prediction and mitigation of slope failures, landslides still exact a significant social, economic and environmental toll in the hilly terrains. The major pitfalls are inadequate understanding of the underlying mechanism of slope failure and the interplay of causative factors of slope failures. However, recently, ample pioneering work has been done by many researchers employing conventional and numerical simulation approaches, and a much better understanding of rock slope engineering practices has been achieved [13, $14,18,20,22,23,38,50,51,55,61]$. In different sections of the Uttarakhand Himalayas, noteworthy studies on slope stability have been carried out by various researchers and organizations, which have provided reasonable and rational insights into environmental fragility, particularly in areas traversed by major and minor tectonic structures $[18,20,52,54,60,67,69]$. Although much work has been done, certain sections within the Himalayan terrain still need to be explored and undergo proper geotechnical assessment.

According to the National Institute of Disaster Management (NIDM), a significant portion of Uttarakhand state is highly prone to landslides. The National Disaster Management Authority (NDMA) prepared a landslide hazard zonation map of Uttarakhand, designating the study area as highly vulnerable. Uttarakhand state is well known for severe natural hazards such as landslides, floods, cloudbursts, seismicity, etc. These hazards are interlinked; the occurrence of one may trigger or increase the intensity of another, and the impacts of such events are disastrous. Recently, the state had such a disastrous event in
Kedarnath and the nearby areas. On 16 and 17 June 2013, Uttarakhand experienced the fury of nature; the area witnessed flash floods and large-scale landslides. This is considered the nation's worst natural disaster since the tsunami of 2004. Kedarnath valley of Uttarakhand and the adjoining areas received exceptionally heavy rainfall, about $375 \%$ more than the benchmark rainfall. The area also experienced extensive cloudbursts, which caused melting of Chorabari Glacier upstream of Kedarnath. Consequently, the Mandakini River experienced heavy floods near Gaurikund, Ukhimath, Agastmuni and Rudraprayag in Uttarakhand state. The village of Rambara, close to Kedarnath, was completely washed away because of the massive flow of debris; many hotels and shops were swept away, leaving no signs of civilization [70]. Rao et al. [39] reported that post-disaster satellite imagery showed that the river banks along the Kedarnath valley had been completely eroded. According to statistics provided by the Uttarakhand Government on 16 July 2013, more than 5700 people were presumed dead. Destruction of bridges and roads caused severe injuries and a significant death toll. Rautela [40] compiled the sequence of events occurring during the Kedarnath tragedy and summarized the aftermath issues, also reporting that approximately 4094 persons were lost just in Mandakini Valley. Several other researchers and organizations reported on the damage caused, triggering factors, terrain response and rescue programmes during the disaster, and some also proposed reconstruction solutions to recover from such disasters $[11,65,68]$. Flash floods during the disaster triggered many large- and smallscale landslides in the region and weakened the stability of slopes in the long term. Many road cut slopes were washed out completely and several sections were significantly affected. The NH-58, which connects Delhi to Badrinath, also experienced deterioration of the cut slopes. This route is important as the road experiences heavy vehicular traffic year round, which increases exponentially during summer because of extensive tourism and the pilgrimage season. The road cut slopes in the region need to be assessed for the probability of failure and accordingly implementation of remedial measures is a prerequisite to attaining better safety and economics along the highway. During the preliminary and feasibility stages of the project, rock mass classification methods provide a reasonable overview of stability [9]. The present study attempted to characterize vulnerable road cut slopes along $\mathrm{NH}-58$ from Kaliyasaur to Rudraprayag by using a rock mass classification tool. Moreover, structurally controlled failures were identified by employing kinematic analysis. Accordingly, remedial measures are suggested to improve the stability grade of slopes for safer and faster economic growth in the region. 


\section{Study area}

The study area lies in the Rudraprayag district, which covers an area of about $2439^{2} \mathrm{~km}$ and lies between latitude $30^{\circ} 19^{\prime} 00^{\prime \prime}$ and $30^{\circ} 49^{\prime} \mathrm{N}$ and longitude $78^{\circ} 49^{\prime}$ and $79^{\circ} 21^{\prime}$ $13^{\prime \prime}$ E. It falls under Toposheet nos. $53 \mathrm{~J}$ and $53 \mathrm{~N}$. The area can be approached from Rishikesh and Dehradun via a motorable metalled road. However, railway links are not available in the district. The average annual rainfall within is about $1485 \mathrm{~mm}$. The investigated road cut slopes lie along NH-58 from Kaliyasaur to Rudraprayag in Alaknanda valley. This route plays an important role in transportation and communication up to the remote areas of the terrain. Geologically, the study area lies at the northeastern flank of the Garhwal Syncline. The studied locations from S1 to S7 were marked in satellite imagery (Fig. 1). The study area mainly comprises the Rautgara Formation of the Damtha Group of the outer Lesser Himalayas, which is well exposed along road cut sections from Srinagar to Rudraprayag. According to Kumar and Agrawal [19], the Rautgara Formation is best developed in the Alaknanda valley.

\section{Methodology}

Vulnerable road cut slopes along National Highway 58 from Kaliyasaur to Rudraprayag were identified during the field survey and investigated in detail via rock mass classification schemes including the rock mass rating (RMR), continuous slope mass rating (CSMR) and geological strength index (GSI). Bieniawski [4] published a rock mass classification scheme, also called the Geomechanics Classification or Rock Mass Rating (RMR) system. It is an internationally accepted and widely used rock mass classification tool for evaluating the quality of the rock mass $[28,31,36,62]$. This classification system can be used to determine the quality of rock masses and is widely employed to estimate the stand-up time for unsupported spans during underground excavations. Furthermore, it is widely used to calculate the elastic modulus, cohesion and angle of internal friction of the jointed rock mass. Over the years, this system has been successively refined as more case records have been examined [5-8]. The RMR method includes six parameters: the uniaxial compressive strength (UCS) of intact rock material, rock quality designation (RQD\%), spacing of discontinuities, condition of discontinuities, groundwater conditions and orientation of discontinuities with respect to slope/ mine/tunnel/foundation. However, for slopes, the adjustment factor for orientation is qualitative, which poses slight subjectivity. to evaluate the stability of rock slopes, Romana [41] proposed a classification system called the Slope Mass Rating (SMR) system. By experience and more case histories, the SMR has been refined many times since its development $[1,42-46]$. It is an exhaustive and extensively used classification system for slope stability evaluation $[2,12,14,33]$. The $\mathrm{SMR}$ is calculated from Bieniawski's $\mathrm{RMR}_{\text {basic, }}$ adding certain adjustment factors illustrated below. $\mathrm{RMR}_{\text {basic }}$ includes the first five parameters of RMR, excluding the orientation factor. Since the SMR involves quantitative consideration of the orientation of discontinuities within the rock mass, the SMR value for a particular slope can be calculated by the following formula:

$$
\mathrm{SMR}=\mathrm{RMR}_{\text {basic }}+\left(F_{1} \times F_{2} \times F_{3}\right)+F_{4}
$$

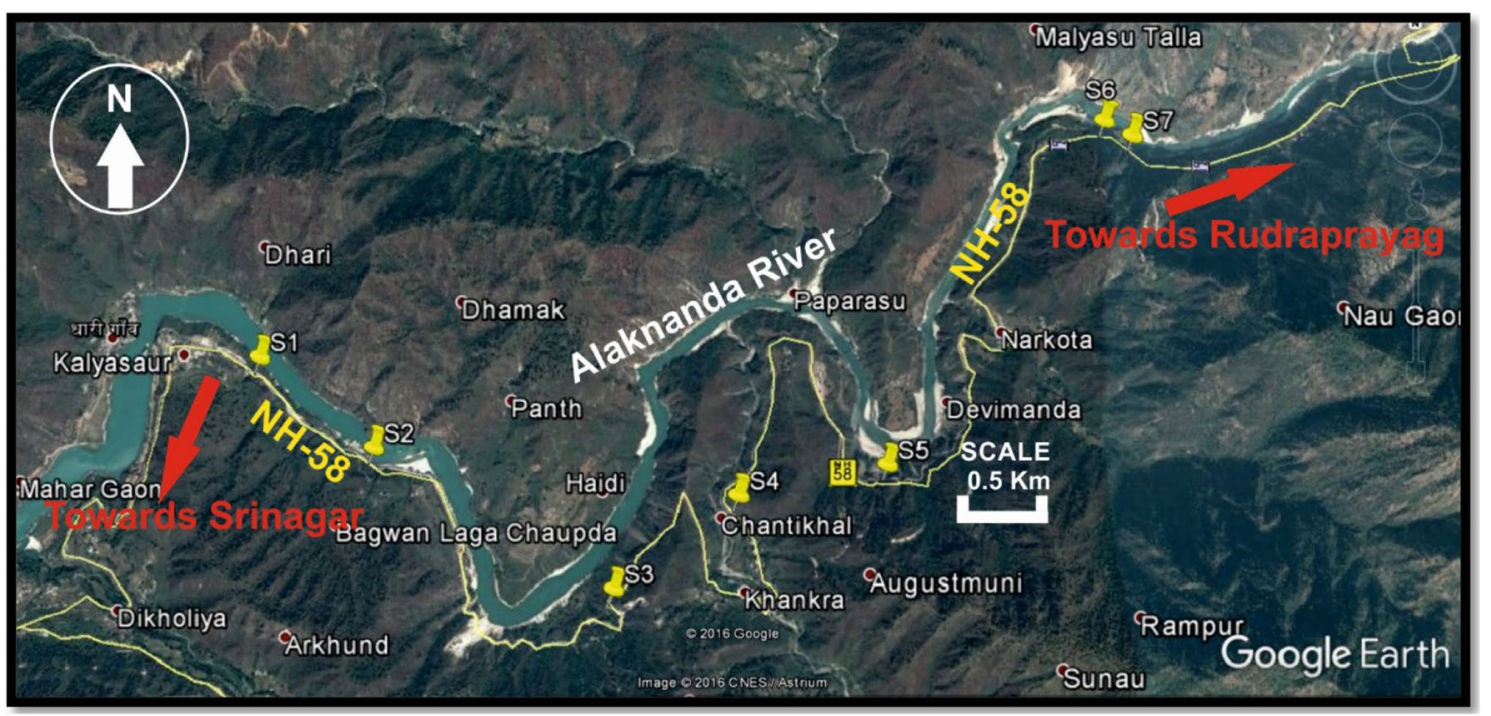

Fig. 1 Satellite imagery showing the study area along NH-58 from Kaliyasaur to Rudraprayag 
where $\mathrm{RMR}_{\text {Basic }}$ is evaluated according to Bieniawski [8]. $F_{1}$, $F_{2}$ and $F_{3}$ are adjustment factors related to the orientation of discontinuities with respect to the slope, and $F_{4}$ is the correction factor for the method of excavation.

Furthermore, Tomás et al. [66] proposed continuous functions for calculating the adjustment factors $\left(F_{1}, F_{2}\right.$ and $F_{3}$ ) as illustrated below. The CSMR is widely recommended over the SMR because the continuous functions in the CSMR reduce the ambiguity that arises because of the border value and provide a better approximation of the stability grade.

$F_{1}=\frac{16}{25}-\frac{3}{500} \arctan \left(\frac{1}{10}(|A|-17)\right)$

where $A=$ laj-asl for planar failure; $A=$ laj - as $-180^{\circ} \mathrm{I}$ for toppling failure; $A=$ lai-asl for wedge failure.

$F_{2}=\frac{9}{16}+\frac{1}{195} \arctan \left(\frac{17}{100} B-5\right)$

where $B=\beta j$ for planar failure; $B=\beta$ i for wedge failure; $F_{2}$ remains 1 for toppling mode of failure.

$F_{3}=-30+\frac{1}{3} \arctan C$ (Planar and Wedge Failure)

where $C=\beta j-\beta$ s for planar failure; $C=\beta j-\beta$ s for toppling failure.

$F_{3}=-13-\frac{1}{7} \arctan (C-120)$ (Toppling Failure)

where $C=\beta i-\beta s$ for wedge failure.

$a s$ is the dip direction of the slope facet, $a j$ is the dip direction of the joint, $\beta s$ is the dip amount of the slope facet, $\beta j$ is the dip amount of the joint, $a i$ is the dip direction of the line formed by the intersection of two joints and $\beta i$ is the amount of plunge of the line formed by the intersection of two joints.

The adjustment factor for the method of excavation $\left(i_{4}\right)$ was fixed empirically as follows: The slope stability grade at discrete locations was determined along the abovementioned road section.

The Geological Strength Index (GSI) is a widely used rock mass classification system that is estimated by visual inspection in the field. As it does not consider the orientation of the joint, it indicates the strength of the rock mass [22]. It is a unique rock mass classification system that relates several rock mass strength and deformation parameters to a generalized Hoek and Brown failure criterion. The GSI is estimated by blockiness and the prevailing joint surface conditions at the site. It is recommended to assign a range of GSI values instead of a single GSI value to a particular rock mass. However, as GSI values are directly used in various failure criteria and numerical modeling techniques, a single value is assigned for a particular site.
To overcome this, Sonmez and Ulusay $[63,64]$ proposed two indices: the surface condition rating (SCR) and structure rating (SR). The former is related to roughness, weathering and infilling of joints, and the latter is calculated by the volumetric joint count. These indices enable users to quantitatively assess the GSI at a particular site.

$\mathrm{SR}=-17 \ln (\mathrm{JV})+79.8$

$\mathrm{SCR}=\mathrm{Rr}+\mathrm{Rw}+\mathrm{Rf}$

where $\mathrm{Jv}=$ volumetric joint count; $\mathrm{Rr}=$ roughness rating; $\mathrm{Rw}=$ weathering rating; $\mathrm{Rf}=$ infilling rating.

Kinematic analysis is widely used to evaluate the potential for various structurally controlled failures (planar, wedge and toppling) due to the presence of unfavourably oriented discontinuities within the rock mass $[3,57]$. Planar failure is likely to occur when a discontinuity dips in the same direction (within $20^{\circ}$ ) as the slope, provided that dip amount of the joint is smaller than the inclination of the slope angle, and it should be greater than the friction angle [16]. Wedge failure is likely to occur when the line formed by the intersection of two discontinuities, forming the wedge-shaped block, plunges in the same direction as the slope face, and the amount of plunge should be less than the slope angle but greater than the friction angle [16]. Toppling failure may result when discontinuities dip in the opposite direction from that of the slope by a very steep angle, i.e. $\geq 75^{\circ}[16]$.

\section{Results and discussion}

Seven potential slopes were identified during a field survey along NH-58 from Kaliyasaur to Rudraprayag in Uttarakhand, India. Field data pertinent to slope stability were carefully collected by considering the geological and geotechnical complexities of the precarious Himalayan terrain. The rock mass encountered in the patch was very fragile with multiple sets of persistent discontinuities. Most of the investigated slopes comprise three sets of discontinuities along with some randomly oriented sets forming blocks of different sizes. The prevailing site conditions depicting various structurally controlled failures are illustrated in Fig. 2.

The rock mass characterization was made by assessing the various RMR parameters. Accordingly, ratings were assigned to each parameter. Representative intact rock samples were collected from all sites and three NX-sized ( $54.7 \mathrm{~mm}$ in diameter) core samples were prepared from each site to determine the compressive strength (Table 1). The test was conducted according to the standards of the International Society of Rock Mechanics [17]. Irrespective of orientation, the presence of joints or fracture frequency largely influences the quality of the rock mass. The rock 
Fig. 2 Unstable conditions favouring structurally controlled failures at road cut slopes along $\mathrm{NH}-58$ from Kaliyasaur to Rudraprayag. a Extensively folded discontinuities showing a high stress regime and toppling failure conditions (slope 2); b large persistent discontinuities showing daylight conditions favouring planar failure (slope 3); c rock mass with large and persistent discontinuities prone to the planar and wedge mode of failure (slope 4); $\mathbf{d}$ blocky and highly fractured rock mass forming wedge failure (slope 5); e persistent discontinuities forming a favourable condition for the planar mode of failure (slope 7)

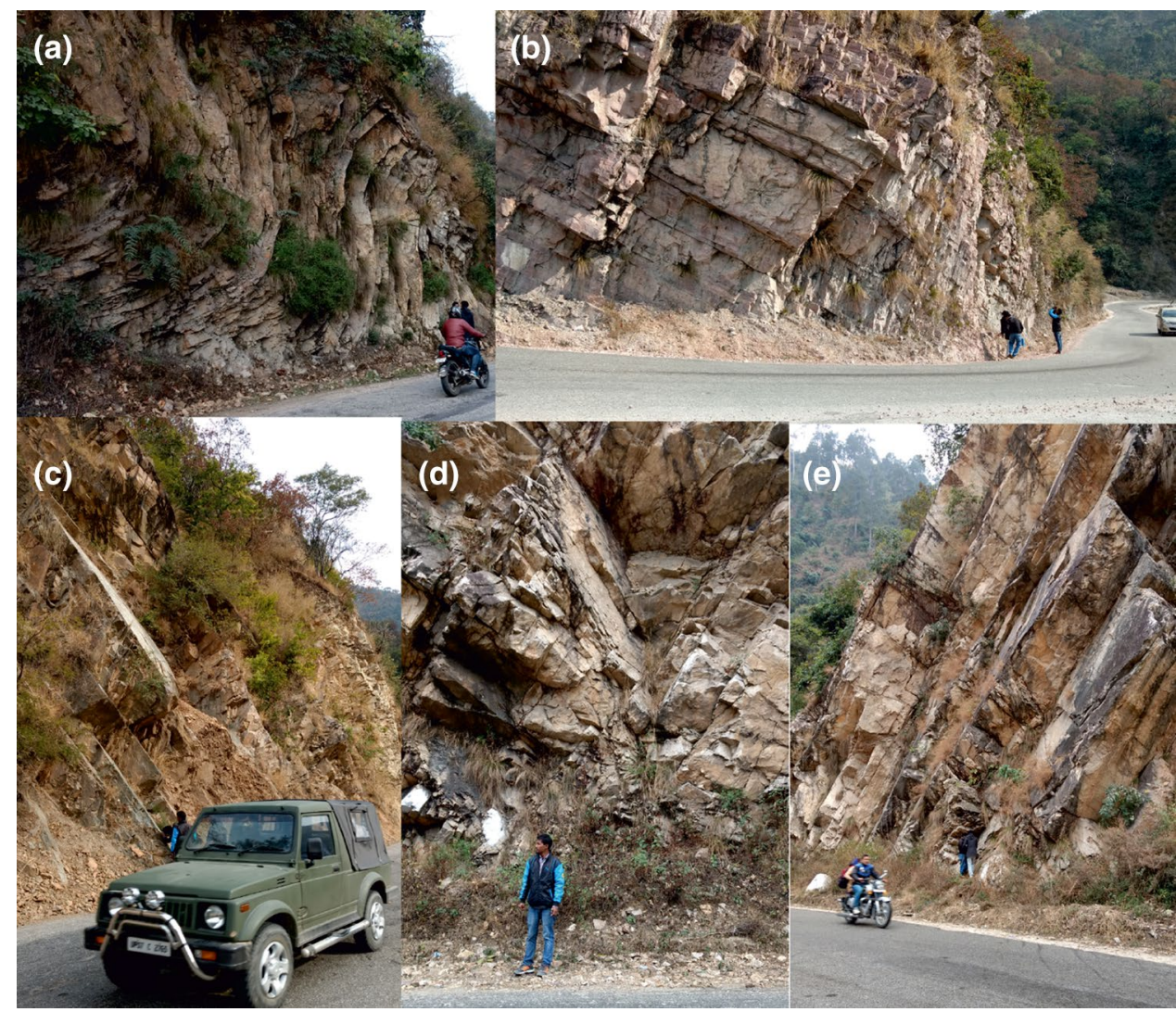

Table 1 UCS and RQD at the investigated sites along $\mathrm{NH}-58$

\begin{tabular}{lll}
\hline Slope & UCS (MPa) & RQD\% \\
\hline S1 & $49,53,54$ & 34.7 \\
S2 & $46,43,49$ & 58.5 \\
S3 & $52,48,57$ & 46.5 \\
S4 & $50,53,47$ & 31.9 \\
S5 & $49,47,51$ & 24.6 \\
S6 & $46,42,47$ & 15.8 \\
S7 & $53,58,51$ & 39.8 \\
\hline
\end{tabular}

quality designation (RQD) introduced by Deere [10] is a widely used index for assessing rock quality on the basis of fracture frequency. The RQD is calculated using the following formula.

$\mathrm{RQD}=\frac{\text { Sum of core pieces having length } \geq 10 \mathrm{~cm}}{\text { Total drill length }} \times 100$

However, when the core is not available, the RQD can be calculated using the following equation [30].

$\mathrm{RQD}=115-3.3\left(\mathrm{~J}_{\mathrm{V}}\right)$

where Jv represents the total number of joints per cubic metre or volumetric joint count.

As cores are not available, the RQD at all sites was calculated by the volumetric joint count (Table 1).
Perpendicular distances between two discontinuities were measured during the field survey and the mean discontinuity spacing at each site was determined. Accordingly, all cut slopes were rated. Discontinuity conditions such as persistence, aperture, roughness, infilling and weathering were determined in the field. Groundwater conditions play a crucial role in the stability of slopes. The presence of water within the joints creates pore pressure and reduces the shear strength of the rock mass. If water is present in clay-filled joints, it acts as a lubricant for structurally controlled failures. Prevailing groundwater conditions were determined during a field survey to rate the groundwater condition parameter. The algebraic sum of the ratings of the above five parameters indicates the basic quality of the rock mass (Table 2). Qualitative estimation of the orientation factor sometimes gives ambiguous results with subjective interpretation of the stability class. Since the orientation factor is an important parameter, much exhaustive and quantitative evaluation is done using the CSMR approach (Table 3).

The orientation of slope facets and major discontinuity sets at each location were recorded and great circles plotted on a stereonet (Fig. 3) to analyse the angular relationship between the slope face and prevailing sets of discontinuities. Such geometric evaluation of the relative orientation enables identifying the varying potential 
Table 2 Ratings of RMR at discrete locations along NH-58

\begin{tabular}{|c|c|c|c|c|c|c|c|}
\hline Parameters & S1 & S2 & $\mathrm{S} 3$ & S4 & S5 & S6 & S7 \\
\hline Unconfined compressive strength & 7 & 7 & 7 & 4 & 4 & 4 & 7 \\
\hline Rock quality designation & 8 & 13 & 8 & 8 & 3 & 3 & 8 \\
\hline Mean discontinuity spacing & 8 & 8 & 8 & 8 & 8 & 8 & 10 \\
\hline \multicolumn{8}{|l|}{ Conditions of discontinuities } \\
\hline Persistence & 1 & 2 & 2 & 2 & 2 & 2 & 1 \\
\hline Aperture & 1 & 1 & 1 & 1 & 1 & 1 & 1 \\
\hline Roughness & 2 & 1 & 2 & 1 & 1 & 2 & 3 \\
\hline Infilling & 6 & 2 & 0 & 4 & 2 & 0 & 6 \\
\hline Weathering & 5 & 3 & 5 & 5 & 5 & 3 & 5 \\
\hline Groundwater & 10 & 10 & 15 & 15 & 10 & 10 & 15 \\
\hline $\mathrm{RMR}_{\text {Basic }}$ & 48 & 44 & 48 & 48 & 36 & 33 & 56 \\
\hline Class number & IV & V & IV & IV & IV & V & IV \\
\hline Description & Poor rock & $\begin{array}{l}\text { Very poor } \\
\text { rock }\end{array}$ & Poor rock & Poor rock & Poor rock & $\begin{array}{l}\text { Very poor } \\
\text { rock }\end{array}$ & Poor rock \\
\hline
\end{tabular}

Table 3 Results of CSMR for different modes of failure at discrete locations

\begin{tabular}{lllllllllll}
\hline Slope & $\mathrm{RMR}_{b}$ & $\begin{array}{l}\text { Type of most pro- } \\
\text { nounced failure }\end{array}$ & $F_{1}$ & $F_{2}$ & $F_{3}$ & $F_{4}$ & CSMR & Class & Stability grade \\
\hline S1 & 48 & Wedge (J1-J2) & 0.89 & 0.37 & 59.6 & 0 & 28 & IV & Unstable \\
S2 & 44 & Toppling (J1) & 0.85 & 1.0 & 25.6 & 0 & 22 & IV & Unstable \\
S3 & 48 & Planar (J1) & 0.41 & 0.88 & 59.5 & 0 & 27 & IV & Unstable \\
& & Wedge (J1-J2) & 0.21 & 0.22 & 59.7 & 0 & 45 & III & Partially stable \\
S4 & \multirow{2}{*}{48} & Planar (J3) & 0.45 & 0.98 & 53.8 & 8 & 32 & IV & Unstable \\
& & Wedge (J1-J2-J3) & 0.24 & 0.96 & 58.9 & 8 & 42 & III & Partially stable \\
S5 & \multirow{2}{*}{36} & Planar (J2) & 0.83 & 0.86 & -59.5 & 10 & 4 & V & Completely unstable \\
& & Wedge (J2-J3) & 0.23 & 0.76 & -59.5 & 10 & 36 & IV & Unstable \\
S6 & 33 & Planar (J1) & 0.67 & 0.91 & -59.4 & 8 & 4 & V & Completely unstable \\
S7 & 56 & Planar (J1) & 0.41 & 0.97 & -58.7 & 8 & 41 & III & Partially stable \\
\hline
\end{tabular}

of structurally controlled failures. Orientation of the slope face and prevailing discontinuities was analysed using a Schmidt-type stereonet and the most pronounced mode of failure along with the causative joint set at discrete locations is illustrated in Table 4. Various structurally controlled failures were determined by critical examination and establishing angular relationships between the slope face and prevailing joints. For instance, slope $\mathrm{S} 2$ is prone to the toppling mode of failure because of steeply dipping joints. The slope face is inclined by $85^{\circ}$ in the $N 040^{\circ}$ direction and critical joint ( $\mathrm{J} 1$ ) forming toppling failure is steeply inclined $\left(78^{\circ}\right)$ in the $\mathrm{N} 230^{\circ}$ direction. The steep angle and the angle between the dip direction $\left(195^{\circ}\right)$ favour toppling failure. The planar mode of failure is the most prominent in the studied region. Planar failure is likely to occur at slope S3 because of the daylight conditions caused by joint set $\mathrm{J1}$. The dip direction of the slope face and critical joint J1 is nearly parallel to the inclination direction of the slope face and the dip amount of the jointed surface is $40^{\circ}$, i.e. sufficiently less than the slope inclination and greater than the friction angle of the joint. These conditions together cause a planar mode of failure at slope S3. Unlike toppling and planar failure, wedge failure is formed by a critical combination or intersection of two sets of joints. The probability of the wedge mode of failure is controlled by the orientation of the line formed by the intersection. As witnessed in slope $\mathrm{S} 5$, the great circles of joint set $\mathrm{J} 2$ and $\mathrm{J} 3$ intersected in such a way that the point formed by their intersection fell in the critical zone between the great circle of slope and friction. This indicates that the line formed by their intesection plunges in the direction of the slope face with less plunge, thereby forming the critical conditions of wedge failure.

The classification of the rock mass via the GSI system is an important component of rock slope engineering practices. It is a simple, fast and reliable classification system primarily based on the visual inspection of certain geological parameters. The structural conditions 


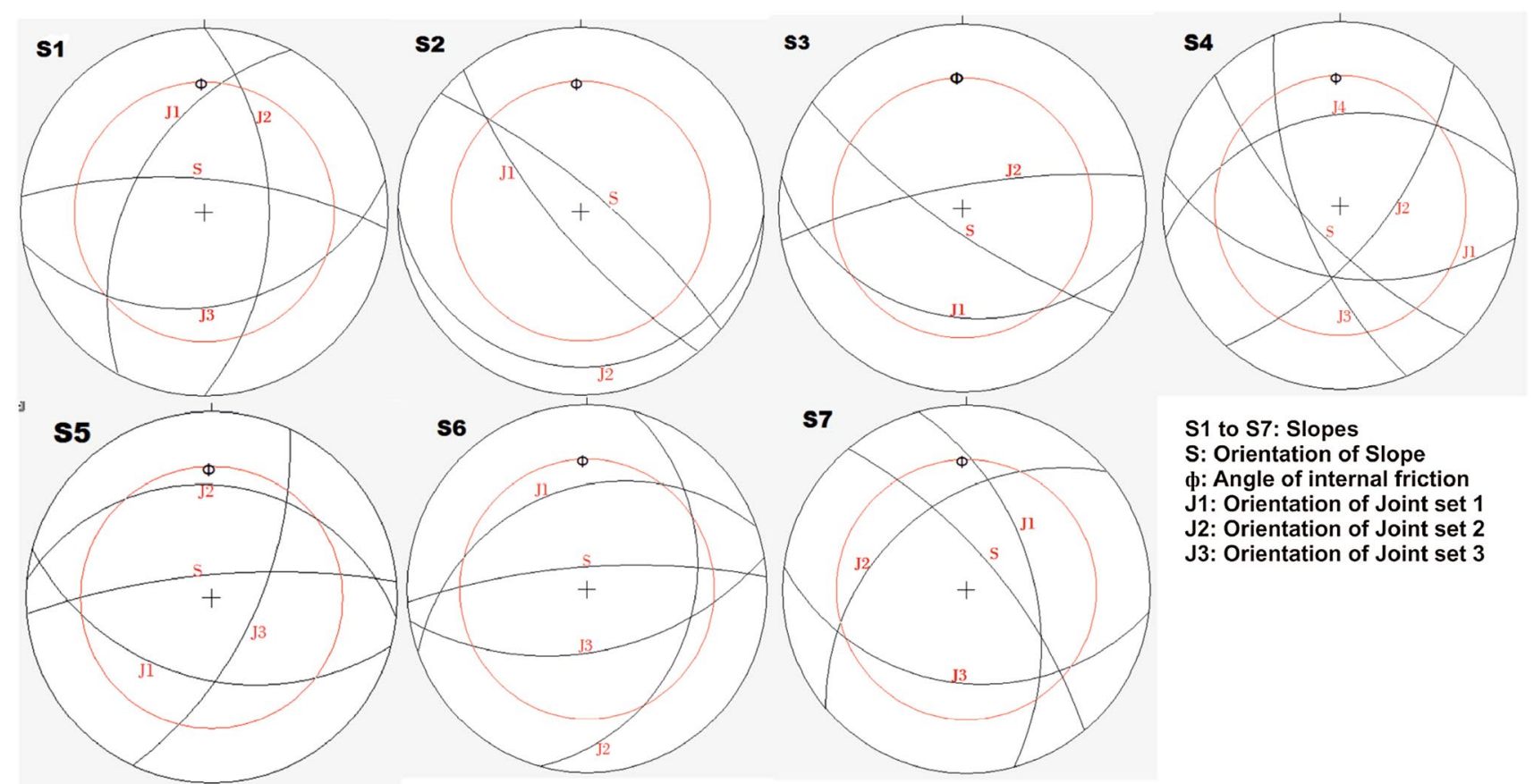

Fig. 3 Kinematic analysis of road cut slopes along NH-58 from Kaliyasaur to Rudraprayag

Table 4 Orientation of slope and joints in all investigated slopes

\begin{tabular}{lllllll}
\hline Slope & \multicolumn{2}{l}{ Orientation (amount/direction) in degrees } & \multicolumn{2}{l}{ Prominent type of failure } \\
\cline { 2 - 6 } & Slope face & Joint (J1) & Joint (J2) & Joint (J3) & Joint (J4) & \\
\hline S1 & $75^{\circ} / 005^{\circ}$ & $56^{\circ} / 298^{\circ}$ & $61^{\circ} / 090^{\circ}$ & $47^{\circ} / 170^{\circ}$ & - & Wedge (J1-J2) \\
S2 & $80^{\circ} / 040^{\circ}$ & $78^{\circ} / 230^{\circ}$ & $16^{\circ} / 181^{\circ}$ & - & - & Toppling (J1) \\
S3 & $80^{\circ} / 215^{\circ}$ & $40^{\circ} / 190^{\circ}$ & $80^{\circ} / 350^{\circ}$ & - & - & Planar (J1) and wedge (J1-J2) \\
S4 & $75^{\circ} / 225^{\circ}$ & $58^{\circ} / 190^{\circ}$ & $70^{\circ} / 130^{\circ}$ & $72^{\circ} / 248^{\circ}$ & $49^{\circ} / 350^{\circ}$ & Planar (J3) and wedge (J1-J2-J3) \\
S5 & $80^{\circ} / 355^{\circ}$ & $54^{\circ} / 195^{\circ}$ & $39^{\circ} / 006^{\circ}$ & $70^{\circ} / 115^{\circ}$ & - & Planar (J2) and wedge (J2-J3) \\
S6 & $80^{\circ} / 356^{\circ}$ & $44^{\circ} / 340^{\circ}$ & $40^{\circ} / 105^{\circ}$ & $62^{\circ} / 170^{\circ}$ & - & Planar (J1) \\
S7 & $75^{\circ} / 050^{\circ}$ & $60^{\circ} / 075^{\circ}$ & $51^{\circ} / 320^{\circ}$ & $48^{\circ} / 187^{\circ}$ & - & Planar (J1) \\
\hline
\end{tabular}

in terms of blockiness of the rock mass and joint conditions, which are related to roughness, weathering and infilling within the joints, are the key characterizing parameters in the GSI system. The volumetric joint count and joints conditions were determined in the field (Table 5). The outcomes obtained by different proxies $\left(\mathrm{RMR}_{\text {basic, }} \mathrm{GSI}\right.$, kinematic analysis and $\left.\mathrm{CSMR}\right)$ are illustrated in Table 5.

Quantified GSI values are illustrated in the chart (Fig. 4). The quantified GSI values can be used for detailed appraisal by a sophisticated numerical simulation tool. Furthermore, the GSI values and RMRb of the investigated cut slopes were compared, showing a linear correlation (Fig. 5). The outcomes obtained by different proxies have been summarized in Table 6 .
Table 5 GSI values of the investigated slopes along $\mathrm{NH}-58$

\begin{tabular}{lllcl}
\hline Slope & Jv & $\mathrm{SR}=-17.5 \mathrm{Ln}(\mathrm{Jv})+79.8$ & $\mathrm{SCR}=\mathrm{Rr}+\mathrm{Rw}+\mathrm{Rf}$ & $\mathrm{GSI}$ \\
\hline S1 & 24.31 & 23.96 & 13 & 44 \\
S2 & 17.10 & 30.12 & 6 & 30 \\
S3 & 20.74 & 26.74 & 7 & 31 \\
S4 & 25.17 & 23.35 & 10 & 37 \\
S5 & 27.37 & 21.88 & 8 & 32 \\
S6 & 30.05 & 20.25 & 5 & 24 \\
S7 & 22.76 & 25.11 & 14 & 47 \\
\hline
\end{tabular}

$J V$ volumetric joint count, $S R$ structure rating, $S C R$ surface condition rating, $R r$ rating of roughness, $R w$ rating of weathering, $R f$ rating of infilling, GSI geological strength index 


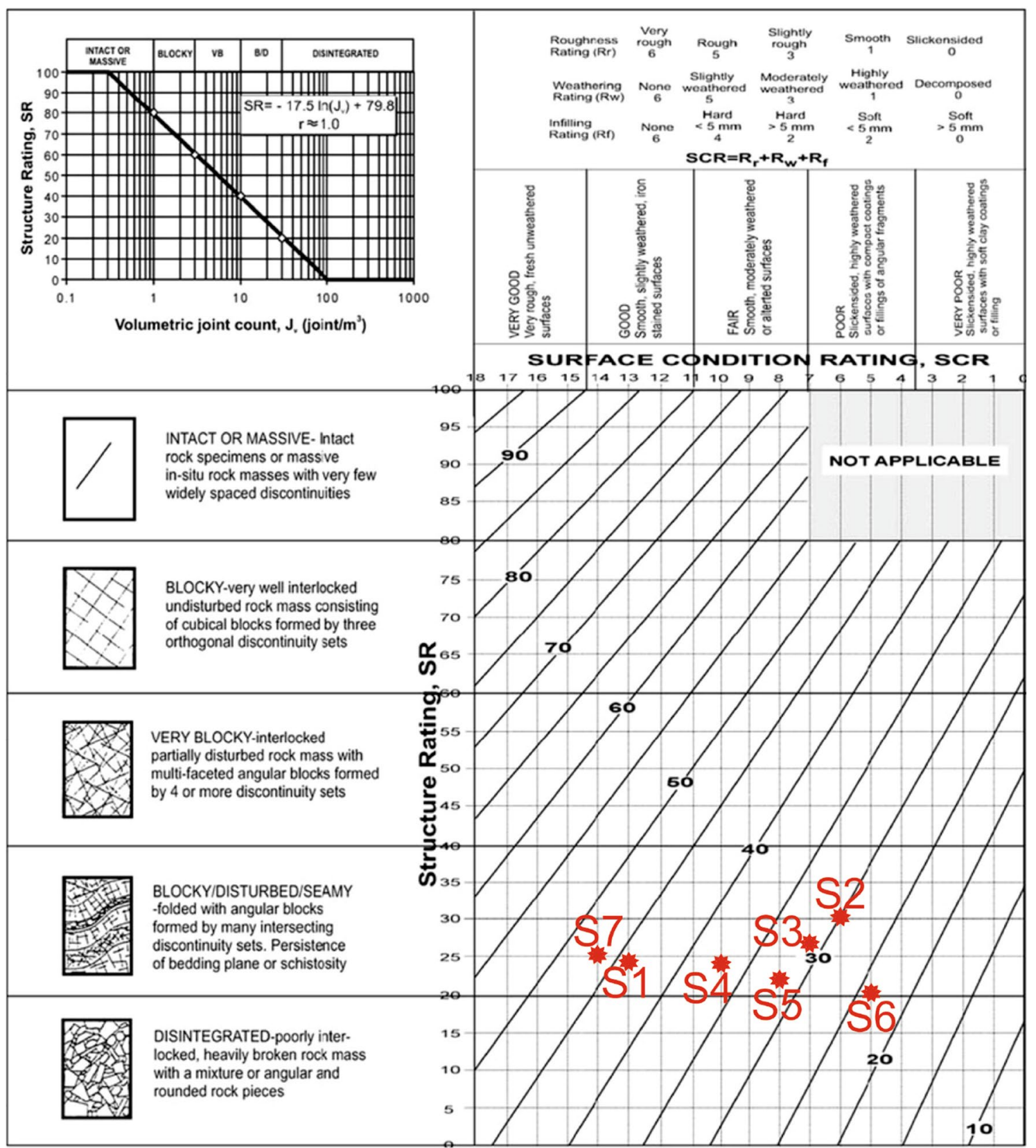

Fig. 4 GSI values of road cut slopes by SR and SCR

\section{Conclusions}

Rock mass classification of road cut slopes is an integral part of rock slope engineering practices. During the preliminary stages, such methods provide quick and cost-effective assessment of the stability grade of the rock mass. RMR, CSMR and GSI classification methods provide reasonable insight into existing stability grades of road cut slopes in the highly precarious Himalayan terrain. According to CSMR, most of the investigated slopes fall under the completely unstable to unstable stability grades. Stability evaluation by the CSMR method surmounts the uncertainty arising from marginal values at the class interval. Completely unstable slopes ought to be given appropriate and immediate treatment. Depending on the size of the potential falling blocks, nets must be installed on the sections at risk. Different rock mass reinforcement techniques such as rock bolting, grouting and shotcrete should be employed for safer designs along the highway. Kinematic analysis of slopes revealed that many sections along the highway are vulnerable to planar and wedge failures. However, toppling 


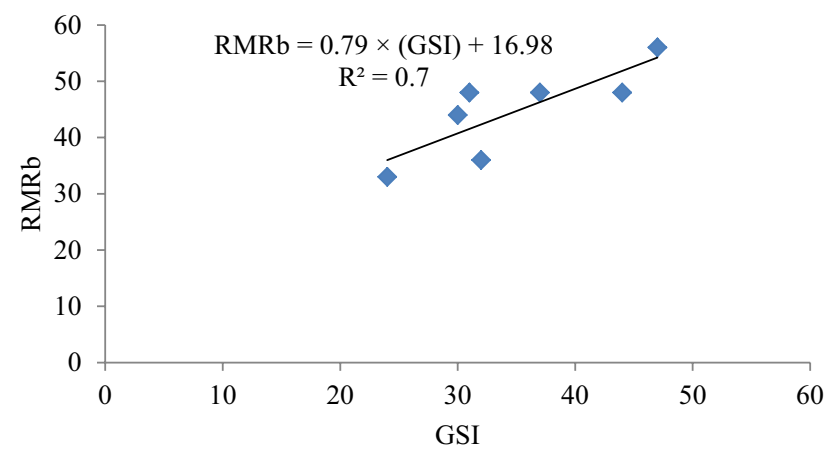

Fig. 5 Correlation between $\mathrm{RMR}_{\text {basic }}$ and GSI

Table 6 The outcomes obtained by different proxies

\begin{tabular}{llllr}
\hline Slope & RMR $_{b}$ & GSI & $\begin{array}{l}\text { Prominent mode of failure by kin- } \\
\text { ematic analysis (causative joint) }\end{array}$ & CSMR \\
\hline S1 & 48 & 44 & Wedge (J1-J2) & 28 \\
S2 & 44 & 30 & Toppling (J1) & 22 \\
S3 & 48 & 31 & Planar (J1) & 27 \\
& & & Wedge (J1-J2) & 45 \\
S4 & 48 & \multirow{2}{*}{37} & Planar (J3) & 32 \\
& & & Wedge (J1-J2-J3) & 42 \\
S5 & 36 & \multirow{2}{*}{32} & Planar (J2) & 4 \\
& & & Wedge (J2-J3) & 36 \\
S6 & 33 & 24 & Planar (J1) & 41 \\
S7 & 56 & 47 & Planar (J1) \\
\hline
\end{tabular}

failure may occur at location S2. Moreover, quantified GSI values are also similar to the basic quality of rock mass obtained by the RMR method. The linear correlation between $\mathrm{RMR}_{\text {basic }}$ and GSI values can be used for further indirect estimation elsewhere. The present work provided a comprehensive understanding of the prevailing stability grades of road cut slopes along $\mathrm{NH}-58$ from Kaliyasaur to Rudraprayag. For swift and hassle-free socio-economic escalation of the region, such studies should be performed in other vulnerable sections of the Himalayas.

Acknowledgements The authors thank the Chairperson, Department of Geology, Aligarh Muslim University, Aligarh, for providing the necessary laboratory facilities during the research. we express their sincere gratitude to Prof. M.E.A. Mondal for frequent discussions and suggestions during the study.

\section{Compliance with ethical standards}

Conflict of interest The authors declare that they have no conflict of interest.

\section{References}

1. Anbalagan R, Sharma S, Raghuvanshi TK (1992) Rock mass stability evaluation using modified SMR approach. In: Proceedings of 6 th natural symposium on rock mechanics, Bangalore, India, pp 258-268

2. Anbazhagan S, Ramesh V, Saranaathan SE (2017) Cut slope stability assessment along ghat road section of Kolli hills, India. Nat Hazards 86:1081-1104

3. Basahel H, Mitri H (2017) Application of rock mass classification systems to rock slope stability assessment: a case study. J Rock Mech Geotech Eng 9:993-1009

4. Bieniawski ZT (1973) Engineering classification of jointed rock masses. Civ Eng S Afr 15:335-344

5. Bieniawski ZT (1974) Geomechanics classification in rock masses and its application in tunnelling. In: Advances in rock mechanics 2, part A. National Academy of Sciences, Washington, pp 27-32

6. Bieniawski ZT (1975) Case studies: Prediction of rock mass behaviour by geomechanics classification. In: Proceedings of 2nd Australia-New Zealand conference Geomechanics, Brisbane, pp 36-41

7. Bieniawski ZT (1976) Rock mass classifications in Engineering. In: Proceedings of the symposium on exploration rock engineering, Johensberg, pp 97-106

8. Bieniawski ZT (1989) Engineering rock mass classification. Wiley, New York, p 251

9. Chaurasia AK, Pandey HK, Nainwal HC, Singh J, Tiwari SK (2017) Stability analysis of rock slopes along Gangadarshan, Pauri, Garhwal, Uttarakhand. J Geol Soc India 89(6):617-740

10. Deere DU (1964) Technical description of rock cores for engineering purposes. Rock Mech Eng Geol 1(1):16-22

11. Dubey CS, Shukla DP, Ningreichon AS, Usham AL (2013) Orthographic control of the Kedarnath disaster. Curr Sci 105(11):1474-1476

12. Ghosh S, Kumar A, Bora A (2014) Analyzing the stability of a failing rock slope for suggesting suitable mitigation measure: a case study from the Theng rockslide, Sikkim Himalayas, India. B Eng Geol Environ 73:931-945

13. Gupta V, Tandon RS (2014) Kinematic rockfall hazard assessment along a transportation corridor in the upper Alaknanda valley, Garhwal Himalaya, India. B Eng Geol Environ. https:// doi.org/10.1007/s10064-014-0623-7

14. Gupta V, Jamir I, Kumar V, Devi M (2017) Geomechanical characterisation of slopes for assessing rockfall hazards in Upper Yamuna valley, Northwest Higher Himalaya, India. Himal Geol 38(2):156-170

15. Hindayar JN, Dasarwar P, Srivastava SP, Kumar NT, Mohan M, Som SK (2016) Dynamicity of the himalayan landslide-a tectono-geotechnical appraisal of the 13th mile landslide, Sikkim. J Geol Soc India 88(8):197-205

16. Hoek E, Bray J (1981) Rock slope engineering, 3rd edn. Institute of Mining and Metallurgy, London

17. ISRM (1978) Suggested methods for determining the uniaxial compressive strength and deformability of rock materials. Int J Rock Mech Min Sci Geomech Abstr 16:135-140

18. Kumar M, Rana S, Pant PD, Patel RC (2017) Slope stability analysis of Balia Nala landslide, Kumaun Lesser Himalaya, Nanital, Uttarakhand, India. Jour Rock Mech Geotech Eng 9:150-158

19. Kumar G, Agrawal (1975) Geology of the Srinagar-Nandprayag Area (Alakananda Valley), Chamoli, Garhwal and Tehri Garhwal Districts, Kumaun Himalaya, Uttar Pradesh. Himal Geol 5:29-59

20. Kumar S, Kumar K, Dogra NN (2017) Rock mass classification and assessment of stability of critical slopes on national highway-22 in Himachal Pradesh. J Geol Soc India 89(4):407-412 
21. Kundu J, Sarkar K, Singh AK (2016) Integrating structural and numerical solutions for road cut slope stability analysis-a case study, India. In: Li (ed) Rock dynamics: from research to engineering. Taylor \& Francis, London. ISBN 978-1-138-02953-8

22. Kundu J, Sarkar K, Singh TN (2017) Qualitative stability assessment of cut slopes along the National Highway-05 around Jhakri area, Himachal Pradesh, India. J Earth Syst Sci 126:112

23. Kundu J, Sarkar K, Singh PK, Singh TN (2018) Deterministic and probabilistic stability analysis of soil slope- a case study. J Geol Soc India 91(4):418-424

24. Mahanta B, Singh HO, Singh PK, Kainthola A, Singh TN (2016) Stability analysis of potential zones along NH-305, India. Nat Hazards 83:1341-1357

25. Mondal MEA, Siddique T, Alam M, Alam MM (2016) Rock mass rating and kinematic analysis for slope stability investigation of Utari Dam in Lalitpur district of Uttar Pradesh, India. J Geol Soc India 87(4):463-468

26. Mondal MEA, Siddique T, Mondal B, Alam MM (2016) SMR geomechanics and kinematic analysis near Rasulpur, Fatehpur Sikri, Uttar Pradesh. J Geol Soc India 87(5):623-627

27. Naithani AK (2007) RMR-A system for characterizing rock mass classification: a case study from Garhwal Himalaya, Uttarakhand. J Geol Soc India 70(4):627-640

28. Naithani AK, Rawat DS, Singh LG, Jain P (2018) Assessment of the excavatability of rock based on rock mass quality: a case study from India. Geotech Geol Eng. https://doi.org/10.1007/ s10706-018-0554-3

29. NDMA (2009) National Disaster Management Guidelines-management of landslides and snow avalanches, 2009. National Disaster Management Authority, Govt of India, New Delhi

30. Palmstrom A (1982) The volumetric joint count-a useful and simple measure of the degree of rock mass jointing. In: Proceedings of 4th international conference of engineering geologist, New Delhi (1982), pp 221-228

31. Pantelidis $L$ (2009) Rock slope stability assessment through rock mass classification systems. J Rock Mech Min Sci 46:315-325

32. Pradhan SP, Siddique T (2019) Mass wasting: an overview. In: Pradhan SP, Vishal V, Singh TN (eds) Landslides: theory, practice and modelling. advances in natural and technological hazards research, vol 50. Springer, Cham, pp 3-20

33. Pradhan SP, Vishal V, Singh TN (2011) Stability of slope in an open cast mine in Jharia Coalfield, India-a slope mass rating approach. Min Eng J 12(10):36-40

34. Pradhan SP, Vishal V, Siddique T (2018) Analysis of rockfall hazard along Himalayan road cut slopes. In: ICGGRM 2018: 20th international conference on geosciences, geology and rock mechanics, Prague, Czechia

35. Prakash C, Aggarwal KK, Sharma VK (2015) Structural control of landslides in eastern Kumaun Himalaya: case study from Sukhidhang-Ladhiya section. J Geol Soc India 86(5):507-512

36. Rad HN, Jalali Z, Jalalifar H (2015) Prediction of rock mass rating system based on continuous functions using Chaos-ANFIS model. J Rock Mech Min Sci 73:1-9

37. Ramesh V, Anbazhagan S (2015) Landslide susceptibility mapping along Kolli hills Ghat road section (India) using frequency ratio, relative effect and fuzzy logic models. Environ Earth Sci 73:8009-8021

38. Ramesh V, Mani S, Baskar M, Kavitha G, Anbazhagan S (2017) Landslide hazard zonation mapping and cut slope stability analyses along Yercaud ghat road (Kuppanur-Yercaud) section, Tamil Nadu, India. Int J Geo-Eng 8(2):1-22

39. Rao KHVD, Rao VV, Dadhwal VK, Diwakar PG (2014) Kedarnath flash floods: a hydrological and hydraulic simulation study. Curr Sci 106(4):598-603

40. Rautela P (2013) Lessons learnt from the deluge of Kedarnath, Uttarakhand, India. Asian J Environ Disaster Manag 5(2):43-51
41. Romana M (1985) New adjustment ratings for application of Bieniawski classification to slopes. In: International symposium on the role of rock mechanics ISRM, Zacatecas, pp 49-53

42. Romana M (1991) SMR classification. In: Proceedings of the 7th congress on rock mechanics 2, ISRM, Aachen, Germany, Balkema, Rotterdam, pp 955-960

43. Romana M (1993) A geomechanics classification for slopes: slope mass rating. In: Hudson J (ed) Comprehensive rock engineering, vol 3. Elsevier, Pergamon, pp 575-600. https://doi. org/10.1016/B978-0-08-042066-0.50029-X

44. Romana M (1995) The geomechanics classification SMR for slope correction. In: Proceedings of the 8th international ISRM congress, pp 1085-1092

45. Romana M, Seron JB, Montalar E (2001) La Clasificacion geomecanica SMR. Aplicacion experencias y validacion. $V$ Simposio Nacional de Laderas Inestables, Madrid, 575-600

46. Romana M, Seron JB, Montalar E (2003) SMR Geomechanics classification: application, experience and validation. ISRMTechnology roadmap for rock mechanics. South African Institute of Mining and Metallurgy, Johannesburg

47. Sah N, Kumar M, Upadhyay R, Dutt S (2018) Hill slope stability of Nanital city, Kumaun Lesser Himalaya, Uttarakhand, India. J Rock Mech Geotech Eng 10(2):280-289

48. Sajwan KS, Sushil K (2016) A Geological Appraisal of Slope Instability in Upper Alaknanda Valley, Uttarakhand Himalaya, India. J Geol Geophys 5(5):1-7

49. Sangra R, Singh Y, Bhat GM, Pandita SK, Hussain G (2017) Geotechnical investigation on slopes failures along the Mughal Road from Bafliaz to Shopian, Jammu and Kashmir, India. J Geol Soc India 90(5):616-622

50. Saranaathan SE, Kannam M (2017) SMR and Kinematic analysis for slope instability along Bodi-Bodimettu ghat section, Tamil Nadu. J Geol Soc India 89(5):589-599

51. Sarkar K, Singh AK, Niyogi A, Behera K, Verma AK, Singh TN (2016) The assessment of Slope Stability along NH-22 in Rampur-Jhakri area, Himachal Pradesh. J Geol Soc India 88:387-393

52. Sarkar S, Kanungo DP, Kumar S (2012) Rock Mass Classification and Slope stability assessment of road cut slopes in Garhwal Himalaya, India. Geotech Geol Eng 30(4):827-840

53. Sati SP, Sunderiyal YP, Rana N, Dangwal S (2011) Recent Landslide in Uttarakhand. Curr Sci 100(11):1617-1620

54. Siddique T, Alam MM, Mondal MEA, Vishal V (2015) Slope Mass Rating and Kinematic analysis of slopes along National Highway-58, near Jonk, Rishikesh, India. J Rock Mech Geotech Eng 7(5):600-606

55. Siddique T, Pradhan SP, Vishal V (2016) Road cut slope stability investigation along NH-58, Near Shivpuri, Uttarakhand. In: National conference on Advances in Geotechnical Engineering, Aligarh, pp 66-70

56. Siddique T, Pradhan SP (2018) Stability and sensitivity analysis of Himalayan road cut debris slopes: an investigation along $\mathrm{NH}-58$, India. Nat Hazards. https://doi.org/10.1007/s1106 9-018-3317-9

57. Siddique T, Pradhan SP, Vishal V, Mondal MEA, Singh TN (2017) Stability assessment of Himalayan road cut slopes along National Highway 58, India. Environ Earth Sci 76:759. https:// doi.org/10.1007/s12665-017-7091-x

58. Singh H, Som SK (2016) Earthquake triggered landslide-Indian Scenerio. J Geol Soc India 87(1):105-111

59. Singh JL, Tamrakar NK (2017) Slope mass rating around Malekhu-Thopal Khola corridor, Malekhu Central Nepal Lesser Himalaya. Am J Sci Eng Tech 2(1):6-14

60. Singh R, Umrao RK, Singh TN (2014) Stability evaluation of road-cut slopes in the Lesser Himalaya of Uttarakhand, India: 
conventional and numerical approaches. B Eng Geol Environ 73:845-857

61. Singh R, Umrao RK, Singh TN (2017) Hill slope stability analysis using two and three dimesions analysis: a comparitive study. J Geol Soc India 89(3):295-302

62. Singh TN, Pradhan SP, Vishal V (2013) Stability of slopes in a fireprone mine in Jharia coalfield, India. Arab J Geosci 6(2):419-427

63. Sonmez H, Ulusay R (1999) Modifications to the geological strength index (GSI) and their applicability to stability of slopes. J Rock Mech Min Sci 36:743-760

64. Sonmez H, Ulusay R (2002) A discussion on the Hoek- Brown failure criterion and suggested modifications to the criterion verified by slope stability case studies. Yerbilimleri 26:77-99

65. Sundriyal YP, Shukla AD, Rana N, Jayangondaperumal R, Srivastava P, Chamyal LS, Sati SP, Juyal N (2015) Terrain response to the extreme rainfall event of June 2013: evidence from Alaknanda and Mandakini river valleys, Garhwal Himalaya, India. Episodes 38(3):179-188

66. Tomás R, Delgado J, Serón JB (2007) Modification of slope mass rating (SMR) by continuous functions. J Rock Mech Min Sci 44:1062-1069
67. Umrao RK, Singh R, Ahmad M, Singh TN (2011) Stability analysis of cut slopes using continuous slope mass rating and kinematic analysis in Rudraprayag district, Uttarakhand. Geomaterials 1:79-87

68. Uniyal A (2013) Lessons from Kedarnath tragedy of Uttarakhand Himalaya, India. Curr Sci 105(11):1472-1474

69. Vishal V, Pradhan SP, Singh TN (2015) Analysis of slopes in Himalayan terrane along national highway: 109, India. Eng Geol Soc Territ 1:511-515

70. Vishal V, Siddique T, Purohit R, Phophliya MK, Pradhan SP (2017) Hazard assessment in rockfall-prone Himalayan slopes National Highway-58, India: rating and simulation. Nat Hazards 85:487-503

Publisher's Note Springer Nature remains neutral with regard to jurisdictional claims in published maps and institutional affiliations. 